\title{
DETERMINATION OF HEAVY METALS IN PRISTIPOMA FURCATUS AND ACANTHURUS STRIGOSUS FISH SPECIES COLLECTED FROM PULICAT LAKE, CHENNAI
}

\author{
B. Prabhu Dass Batvari ${ }^{1}$ and D. Saravanan ${ }^{2, *}$ \\ ${ }^{1}$ Center for Earth and Atmospheric Science, Sathyabama Institute of Science and Technology, \\ Chennai, India \\ ${ }^{2}$ Centre for Laboratory Animal Technology and Research, Sathyabama Institute of Science and \\ Technology, Chennai, India \\ *E-mail:snegapoorvam@yahoo.com
}

\begin{abstract}
Concentrations of heavy metals namely $\mathrm{Pb}, \mathrm{Zn}, \mathrm{Fe}, \mathrm{Cu}, \mathrm{Cd}$ and $\mathrm{Cr}$ detected in tissue of two fish species (Pristipoma furcatus and Acanthurus strigosus) collected from Pulicate Lake, Chennai mixed with effluent from industries in and around north Chennai. The report shows significant results between the organs of $P$. furcatus and A. strigosus but also significant changes observed in all the metals determined in this study. The concentration of heavy metals in the fish tissue was medium to low. The organs of fish species measured high level of Lead and Iron. Trace metal levels in edible component tissue of fish were within the limit and good for consumption.
\end{abstract}

Keywords: Heavy Metals, Pristipoma furcatus, Acanthurus strigosus, Aquatic Ecosystem, Sediment.

(C) RASĀYAN. All rights reserved

\section{INTRODUCTION}

Trace Heavy metals usually occur in different areas of earth's crust, soil, air, water and all organic matter and are typically distributed by anthropogenic activities such as bond generation, iron steel, steam control plants, glass factories, garbage waste, mining, smelters and foundries, channeling, ignition and traffic. ${ }^{1-5}$ Natural events such as wind, soil erosion and volcanic activity can also spread around them. ${ }^{6-9}$ Due to its toxicity and persistence in the aquatic environment for several decades, heavy metal contamination in marine ecosystem has become a universal phenomenon. ${ }^{10}$ Seafoods like fish, crab and prawn are delicacies and are an essential part of everyday food. The trend of heavy metals to get stored in aquatic animals is of scientific attention in heavy metal geochemistry. The bioavailability of trace heavy metals is the important factor determining tissue metal levels in the marine biota.

Aquatic animals are sensitive to heavy metals when heavy metal levels in sediment and water reach considerable levels. Fishes are more often affected than other animals because of variations in the evolutionary strategies followed by various phyla. ${ }^{11}$ In the food chain, metals stored in crustaceans could be biomagnified and ultimately affect people.

Pulicatis the typical salty water ecosystem, located $60 \mathrm{~km}$ north of Chennai (Fig.-1). Pulicat Lagoon is considered to be the second-largest brackish water body in India measuring 759 square kilometers. Pulicat has a length of about $60 \mathrm{~km}$, the width of $17.5 \mathrm{~km}$ width $360 \mathrm{~km}^{2}$ and its depth (water column) varies between 1 and $10 \mathrm{~m}$. In the previous studies, heavy-metal contamination of sediments, air, fish, algae, mullet, oyster and crop plants in Lake Pulicat was identified as part of an observation and monitoring analysis of anthropogenic activities and pollution in the PulicatLake ${ }^{10-15}$. The aim of the research is to estimate heavy metal pollution rates in two of the common fish species (Pristipomafurcatus and Acanthurusstrigosus), which in the Pulicat lake appear to be of great commercial and ecological significance. Partially or improperly treated effluents from the industrial and domestic area from the 
RASĀYAN J. Chem.

Vol. 13 | No. 1 |195 - 201| January - March | 2020

Ennore Creek and Buckingham Canal finally reach Pulicat Lake through its bare mouth of Bay of Bengal coastal waters. ${ }^{16-18}$

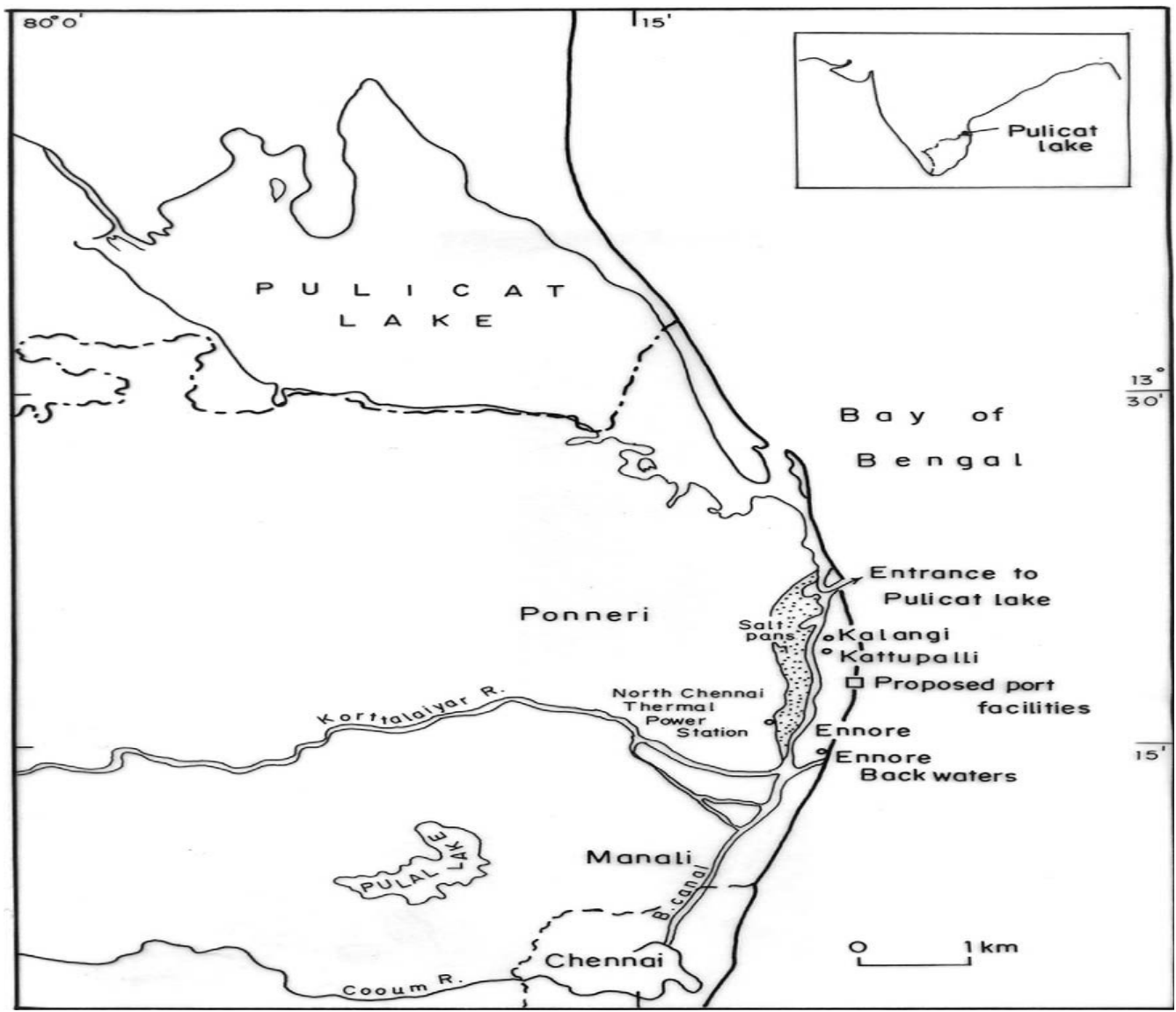

Fig.-1: Map Showing the Study Area

\section{Sampling}

EXPERIMENTAL

Twenty-five samples were collected from pulicat lake with the help of fishing professionals and transport to the lab without any contamination. Each fish species (Pristipomafurcatus and Acanthurusstrigosus) in two seasons (July pre-monsoon and January post-monsoon month). The fish for the test were collected from the mouth of shallow and $10 \mathrm{~km}$ from the upstream of the mouth. At the point of collection, the fish samples were washed with fresh water, and segregated by species and transport to the laboratory and stored in frozen condition until its autopsy.

\section{Preparation of Sample}

Samples (Fish) are brought to room temperature, and with the help of sterile blades, the organs from fish were isolated. One gram of muscle was separated for examination on the dorsal surface of the fish, the entire liver and intestine, and two gills of each specimen. They were washed with double distilled water, dried in filter paper, measured, packed in bags of polyethylene, and held at $-20^{\circ} \mathrm{C}$ until analysis.

\section{Analytical Procedure}

During the digestion, a microwave digester was used. ${ }^{11}$ The (1gram) samples were digested with $5 \mathrm{ml}$ of nitric acid (65 percent) and the samples were kept in temperature after complete digestion, the samples were cooled and $25 \mathrm{ml}$ of double distilled water was added. All treated specimens have been analyzed 
RASĀYAN J. Chem.

Vol. 13 | No. 1 |195 - 201| January - March | 2020

three times using Atomic Absorption Spectrophotometer (Perkin Elmer, AA 700) for metals Cadmium, d, Chromium, Zinc, Lead and iron are represented as $\mu \mathrm{g} / \mathrm{g}$ tissue wet weight. The device was calibrated using standard chemical solutions prepared from commercially available chemical products (Merck, Germany). Analytical blanks were performed in the same manner as specimens and concentrations were calculated using generic formulations formulated in the same acid matrix. Analyzing standard reference material (MESS-1 and DORM-2, National Research Council, Canada) has tested the reliability of data. All reagents used during the research were of analytical grade and throughout the study deionized water was used. All plastics and glassware washed in nitric acid for 15 minutes and rinsed before use with deionized water.

\section{RESULTS AND DISCUSSION}

The heavy metal(copper, cadmium, chromium, zinc, lead and iron) concentrations heavy in muscles, gills, intestines, and liver of P.furcatus and A.strigosus collected during pre-monsoon in the month of July and postmonsoon in the month of January seasons are presented in Table-1. In species Pristipoma, the Average amount of $\mathrm{Cu}$ present is 0.0087 with the deviation of $1.4 \%$, the average amount of $\mathrm{Cu} 0.0087$,

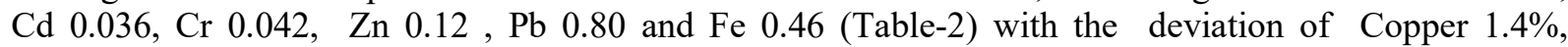
Cadmium 2.5\%, Chromium 3\%, Zinc 15\%, Lead 72\% and Iron 30\% presents in the Pristipomafurcatus and for Acanthurusstrigosus the average of Cooper 0.002, Cadmium 0.037, Chromium 0.026, Zinc 0.11, Lead 0.65 and Iron 0.93 with the deviation of Copper $0.4 \%$, Cadmium 1.5\%, Copper 3.8\%, Zinc 5.9\%, Lead $25 \%$, and Iron 14.95 from the mean observation value.

Table-1: Heavy Metal Concentration in Different Organs of Fishes During Pre-monsoon and Post-monsoon

\begin{tabular}{|c|c|c|c|c|c|c|c|c|}
\hline \multirow{2}{*}{ Seasons } & \multirow{2}{*}{ Species } & \multirow{2}{*}{ Organ } & \multicolumn{5}{|c|}{ Metal $(\mu \mathrm{g} / \mathrm{g})$} & \multirow[b]{2}{*}{ Iron } \\
\hline & & & Copper & Cadmium & Chromium & Zinc & Lead & \\
\hline \multirow{8}{*}{$\begin{array}{l}\tilde{0} \\
0 \\
0 \\
0 \\
0 \\
\sum_{0} \\
0 \\
0 \\
0\end{array}$} & \multirow{4}{*}{$\begin{array}{l}\text { Pristipoma } \\
\text { furcatum }\end{array}$} & Liver & BDL & 0.245 & 0.205 & BDL & 7.21 & 2.775 \\
\hline & & Gills & BDL & 0.095 & 0.015 & 0.315 & 2.096 & 0.792 \\
\hline & & Intestine & BDL & 0.073 & 0.064 & 0.036 & 0.12 & 2.834 \\
\hline & & Muscle & BDL & 0.13 & 0.144 & 0.26 & 2.712 & 0.44 \\
\hline & \multirow{4}{*}{$\begin{array}{l}\text { Acanthurus } \\
\text { strigosus }\end{array}$} & Liver & BDL & 0.127 & 0.338 & 0.091 & 2.8 & 2.187 \\
\hline & & Gills & BDL & 0.17 & 0.182 & 0.446 & 3.032 & 2.016 \\
\hline & & Intestine & BDL & 0.118 & 0.035 & 0.306 & 1.93 & 14.305 \\
\hline & & Muscle & BDL & 0.13 & BDL & 0.228 & 1.754 & 0.496 \\
\hline \multirow{8}{*}{$\begin{array}{l}\tilde{0} \\
0 \\
0 \\
0 \\
\sum_{0}^{0} \\
0 \\
0 \\
0\end{array}$} & \multirow{4}{*}{$\begin{array}{l}\text { Pristipomafurc } \\
\text { atum }\end{array}$} & Liver & 0.123 & 0.183 & 0.29 & 1.53 & 3.998 & 0.598 \\
\hline & & Gills & 0.038 & 0.037 & 0.026 & 0.222 & 0.996 & 1.755 \\
\hline & & Intestine & BDL & 0.042 & 0.049 & 0.208 & 1.206 & 0.995 \\
\hline & & Muscle & 0.047 & 0.043 & 0.077 & 0.159 & 1.064 & 0.661 \\
\hline & \multirow{4}{*}{$\begin{array}{l}\text { Acanthurusstri } \\
\text { gosus }\end{array}$} & Liver & BDL & 0.085 & 0.03 & 0.687 & 2.005 & 1.163 \\
\hline & & Gills & 0.039 & 0.042 & 0.036 & 0.354 & 1.017 & 0.471 \\
\hline & & Intestine & BDL & 0.044 & BDL & 0.357 & 1.137 & 1.525 \\
\hline & & Muscle & BDL & 0.154 & BDL & 0.154 & 1.56 & 0.264 \\
\hline
\end{tabular}

BDL: Below Detection Level

Table-2: Descriptive Measures of Heavy Metals and Organs

\begin{tabular}{c|c|c|c|c|c|c|c|c|c}
\hline & Species & Test & Organ & $\mathrm{Cu}$ & $\mathrm{Cd}$ & $\mathrm{Cr}$ & $\mathrm{Zn}$ & $\mathrm{Pb}$ & $\mathrm{Fe}$ \\
\hline $\mathrm{N}$ & 48 & 48 & 48 & 48 & 48 & 48 & 48 & 48 & 48 \\
\hline Mean & 1.5 & 1.5 & 2.5 & 0.0051 & 0.0357 & 0.0338 & 0.111 & 0.727 & 0.693 \\
\hline $\mathrm{SD}$ & 0.5052 & 0.505 & 1.13 & 0.0108 & 0.0205 & 0.0348 & 0.117 & 0.543 & 1.097 \\
\hline \multirow{2}{*}{} & & Species & $\mathrm{N}$ & Mean & Std. Deviation & Std. Error Mean & & \\
\hline & \multirow{2}{*}{} & $\mathrm{Cu}$ & Pristipoma & 24 & 0.00867 & 0.01396 & 0.00285 & & \\
\cline { 3 - 9 } & & Acanthurus & 24 & 0.00163 & 0.00443 & 0.0009 & & \\
\hline
\end{tabular}


RASĀYAN J. Chem.

Vol. 13 | No. 1 |195 - 201| January - March | 2020

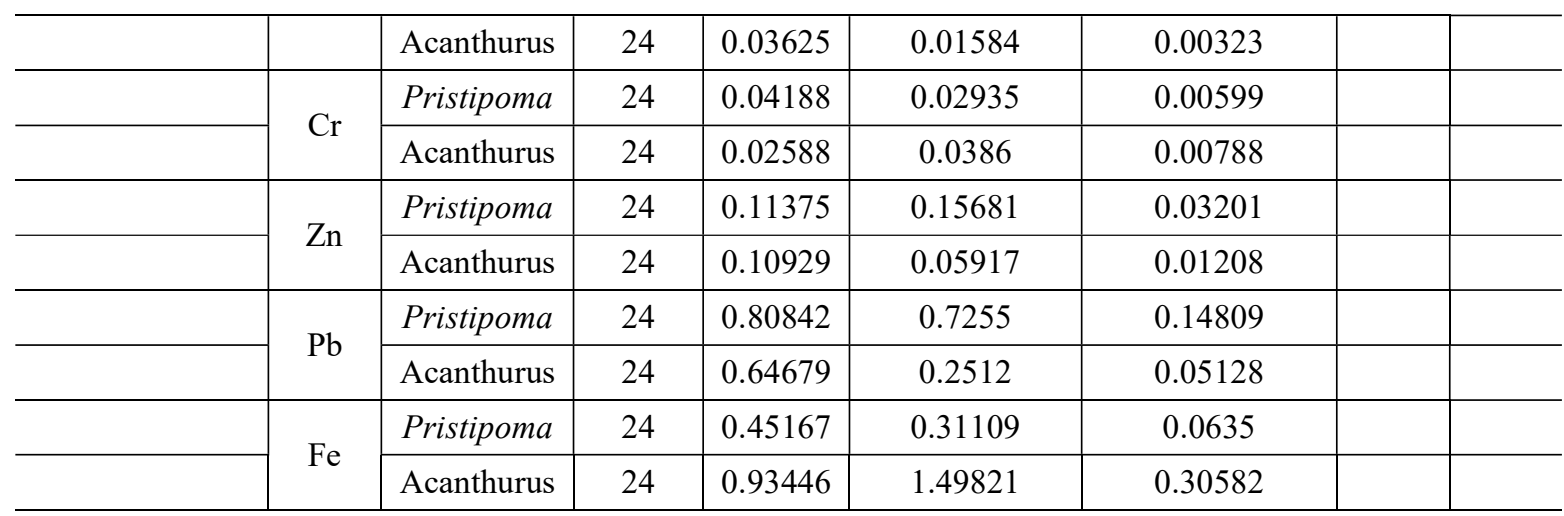

Table-3: Correlation of Species and Metals

\begin{tabular}{c|c|c|c|c|c|c|c}
\hline & $\mathrm{Cu}$ & $\mathrm{Cd}$ & $\mathrm{Cr}$ & $\mathrm{Zn}$ & $\mathrm{Pb}$ & $\mathrm{Fe}$ & Species \\
\hline $\mathrm{Cu}$ & 1 & 0.034 & $0.312^{*}$ & $0.754^{* *}$ & 0.096 & -0.193 & $-0.328^{*}$ \\
\hline $\mathrm{Cd}$ & & 1 & $0.540^{* *}$ & 0.179 & $0.837^{* *}$ & 0.091 & 0.023 \\
\hline $\mathrm{Cr}$ & & & 1 & $0.295^{*}$ & $0.629^{* *}$ & -0.088 & -0.232 \\
\hline $\mathrm{Zn}$ & & & & 1 & 0.173 & -0.105 & -0.019 \\
\hline $\mathrm{Pb}$ & & & & & 1 & 0.033 & -0.15 \\
\hline $\mathrm{Fe}$ & & & & & & 1 & 0.222 \\
\hline Species & & & & & & & 1 \\
\hline
\end{tabular}

The relationship between the Species and Metals Presented in the species of variety are shown in Table3.There is a less degree of a positive association between species and $\mathrm{Cd}$ and $\mathrm{Fe}$ and there is a less degree of a negative association between species and $\mathrm{Cu}, \mathrm{Cr}, \mathrm{Pb} \& \mathrm{Zn}$. There is a significant difference between $\mathrm{Cu}, \mathrm{Cr}$, and $\mathrm{Zn}, \mathrm{Cd}$ with $\mathrm{Cr}$ and $\mathrm{Pb}, \mathrm{Cr}$ with $\mathrm{Zn}$ and $\mathrm{Pb}$. The relationship between the organs and Metals Presented in the species of variety is shown in Table-4. There is a less degree of a positive association between organs and $\mathrm{Fe}$ and there is a less degree of a negative association between organs and $\mathrm{Cu}, \mathrm{Cd}, \mathrm{Cr}$, $\mathrm{Zn} \& \mathrm{~Pb}$. There is a significant difference between $\mathrm{Cr}, \mathrm{Zn}$ and $\mathrm{Pb}$.

Table-4: Correlation of Organs and Metals

\begin{tabular}{c|c|c|c|c|c|c|c}
\hline & Organ & $\mathrm{Cu}$ & $\mathrm{Cd}$ & $\mathrm{Cr}$ & $\mathrm{Zn}$ & $\mathrm{Pb}$ & $\mathrm{Fe}$ \\
\hline Organ & 1 & & & & & & \\
\hline $\mathrm{Cu}$ & -0.265 & 1 & & & & & \\
\hline $\mathrm{Cd}$ & -0.283 & 0.034 & 1 & & & & \\
\hline $\mathrm{Cr}$ & $-0.586^{* *}$ & $0.312^{*}$ & $0.540^{* *}$ & 1 & & & \\
\hline $\mathrm{Zn}$ & $-0.398^{* *}$ & $0.754^{* *}$ & 0.179 & $0.295^{*}$ & 1 & & \\
\hline $\mathrm{Pb}$ & $-0.517^{* *}$ & 0.096 & $0.837^{* *}$ & $0.629^{* *}$ & 0.173 & 1 & \\
\hline $\mathrm{Fe}$ & 0.001 & -0.193 & 0.091 & -0.088 & -0.105 & 0.033 & 1 \\
\hline
\end{tabular}

The present study results of heavy metals absorbtion examined during pre-monsoon period in many tissues of $\mathrm{P}$. furcatus the order appears to be as follows: intestine $\mathrm{Fe}>\mathrm{Pb}>\mathrm{Zn}>\mathrm{Cd}>\mathrm{Cr}>\mathrm{Cu}$; liver $\mathrm{Pb}>$ $\mathrm{Fe}>\mathrm{Cd}>\mathrm{Cr}>\mathrm{Zn}>\mathrm{Cu}$; muscle $\mathrm{Pb}>\mathrm{Fe}>\mathrm{Zn}>\mathrm{Cr}>\mathrm{Cd}>\mathrm{Cu}$ and gill $\mathrm{Pb}>\mathrm{Fe}>\mathrm{Zn}>\mathrm{Cd}>\mathrm{Cr}>$ Curespectively as shown in the Fig.-2. The post monsoon the concentrations of metals in the intestine, liver, muscle and gill of $P$. furcatus the following orderintestine $\mathrm{Fe}>\mathrm{Pb}>\mathrm{Cr}>\mathrm{Cd}>\mathrm{Zn}>\mathrm{Cu}$ : liverPb $>\mathrm{Zn}>\mathrm{Fe}>\mathrm{Cr}>\mathrm{Cd}>\mathrm{Cu}$; mussclePb $>\mathrm{Fe}>\mathrm{Zn}>\mathrm{Cr}>\mathrm{Cd}>\mathrm{Cu}$ andFe $>\mathrm{Pb}>\mathrm{Zn}>\mathrm{Cu}>\mathrm{Cd}>\mathrm{Cr}>$ respectively (Fig.-3). The mean concentrations of $\mathrm{Cd}, \mathrm{Zn}, \mathrm{Pb} \mathrm{Cr}, \mathrm{Cu}$ and $\mathrm{Fe}$ in $P$. furcatusthe following order is sequence during pre-monsoon and post-monsoon $\mathrm{Pb}>\mathrm{Fe}>\mathrm{Zn}>\mathrm{Cd}>\mathrm{Cr}>\mathrm{Cu}(\mathrm{Fig}$.-4). The 
RASĀYAN J. Chem.

Vol. 13 | No. 1 |195 - 201| January - March | 2020

following two metals $\mathrm{Fe}$ and $\mathrm{Pb}$ showing the higher values of Liver, Gills, Intestine and Muscle and the order is given as Liver $>$ Muscle $>$ Intestine $>$ Gills during pre-monsoon and the sequence is shown as Liver $>$ Gills $>$ Muscle $>$ Intestine in the post-monsoon.

The absorption of heavy metals analysed during pre-monsoon period in various organs of $A$. strigosus the sequence seems to be as follows: intestine, $\mathrm{Fe}>\mathrm{Pb}>\mathrm{Zn}>\mathrm{Cd}>\mathrm{Cr}>\mathrm{Cu}$; liver, $\mathrm{Pb}>\mathrm{Fe}>\mathrm{Cr}>\mathrm{Cd}>\mathrm{Zn}>$ $\mathrm{Cu}$; muscle $\mathrm{Pb}>\mathrm{Fe}>\mathrm{Zn}>\mathrm{Cd}>\mathrm{Cr}>\mathrm{Cu}$ and gill $\mathrm{Pb}>\mathrm{Fe}>\mathrm{Zn}>\mathrm{Cd}>\mathrm{Cr}>\mathrm{Cu}$ respectively as given in the Fig.-5. During the post monsoon the concentrations of heavy metals in the intestine, liver, muscle and gill of $A$. strigosus the following sequence $\mathrm{Pb}>\mathrm{Fe}>\mathrm{Zn}>\mathrm{Cd}>\mathrm{Cr}>\mathrm{Cu} ; \mathrm{Pb}>\mathrm{Fe}>\mathrm{Zn}>\mathrm{Cr}>\mathrm{Cd}>\mathrm{Cu} ; \mathrm{Pb}>\mathrm{Fe}>$ $\mathrm{Zn}>\mathrm{Cd}>\mathrm{Cr}>\mathrm{Cu}$ and $\mathrm{Pb}>\mathrm{Fe}>\mathrm{Zn}>\mathrm{Cr}>\mathrm{Cd}>\mathrm{Cu}$ respectively as given in the Fig.- 6 .

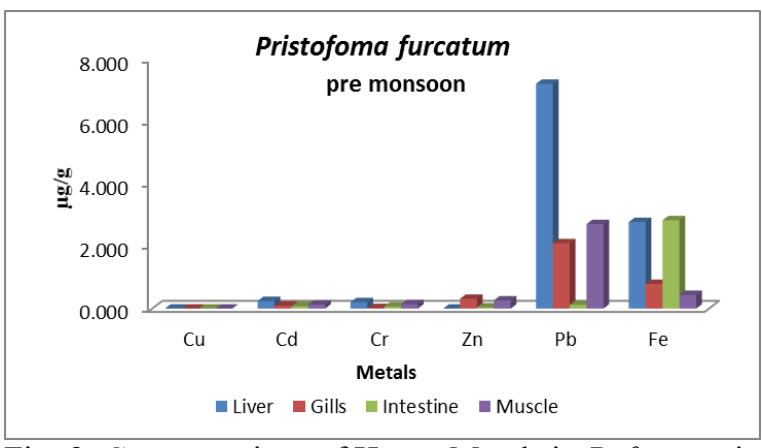

Fig.-2: Concentrations of Heavy Metals in P. furcatusin Pre-monsoon

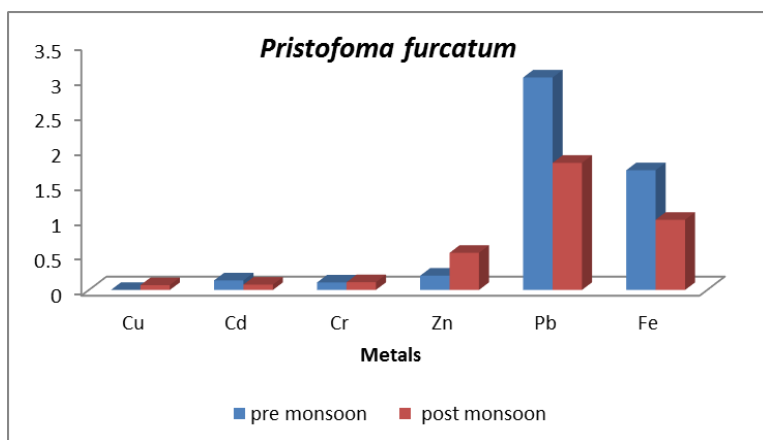

Fig.-4: Differences Between Pre and Post-monsoon in $P$. furcatus

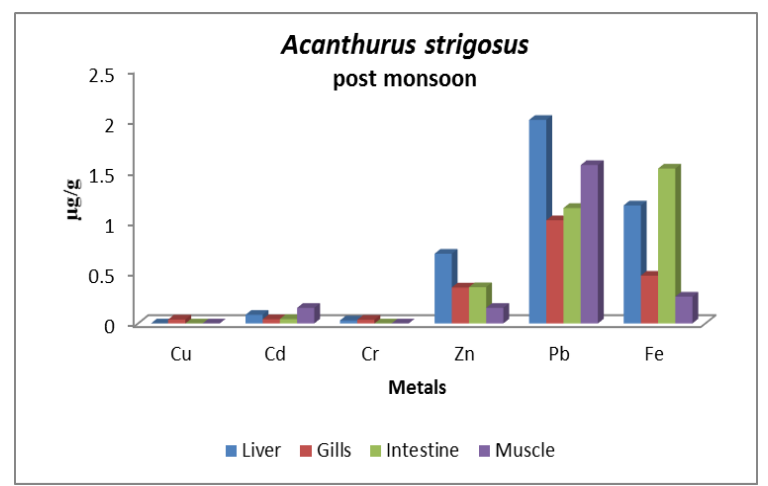

Fig.-6: Concentrations of Heavy Metals in Acanthurusstrigosus in Post-monsoon

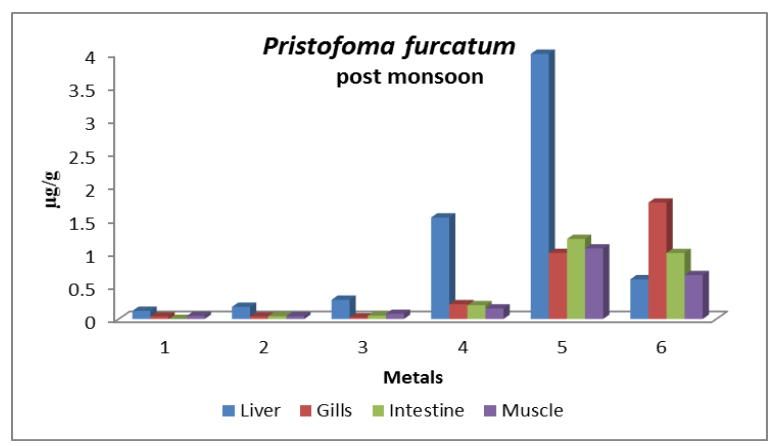

Fig.-3: Concentrations of Heavy Metals in P. furcatus in Post-monsoon

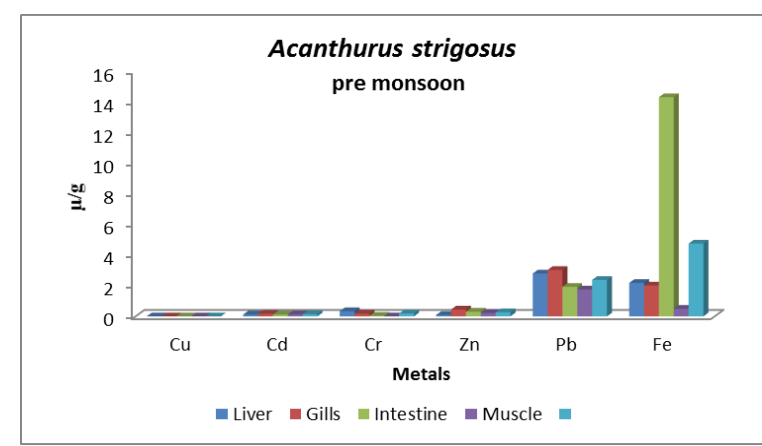

Fig.-5: Concentrations of Heavy Metals in Acanthurusstrigosus in Pre-monsoon

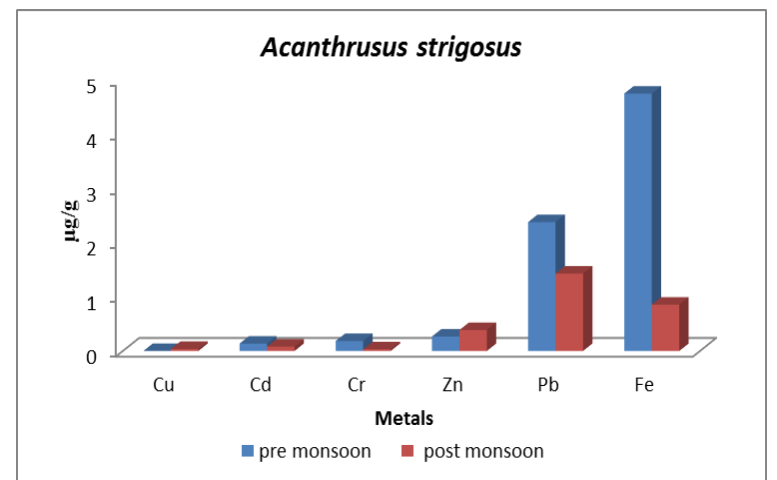

Fig.-7: Differences Between Pre and Post-monsoon in Acanthurusstrigosus 


\section{RASĀYAN J. Chem.}

Vol. 13 | No. 1 |195 - 201| January - March | 2020

The average concentrations of $\mathrm{Cd}, \mathrm{Zn}, \mathrm{Pb} \mathrm{Cr}, \mathrm{Cu}$ and $\mathrm{Fe}$ in $A$. strigosus during pre-monsoon seasons and post monsoon seasons of the following sequence $\mathrm{Fe}>\mathrm{Pb}>\mathrm{Zn}>\mathrm{Cr}>\mathrm{Cd}>\mathrm{Cu}$ as given in the Fig.-7. The metals $\mathrm{Pb}$ and $\mathrm{Fe}$ which shows the higher concentrations in the part of Liver, Intestine, Muscle, Gills and the order is given as Intestine $>$ Gills $>$ Liver $>$ Muscle during the pre-monsoon and in the post monsoon the sequence is shown as Liver $>$ Muscle $>$ Intestine $>$ Gills.

Overall, the highly accumulated metals were found to $\mathrm{be} \mathrm{Pb}$ and $\mathrm{Fe}$, and in both fish, $\mathrm{Cu}$ was the less accumulated (Table-1)metal. The results are similar to earlier studies, which show high concentrations of $\mathrm{Pb}$ and $\mathrm{Fe}$ in shrimp, fish, mullet, oyster and Ulva lactuca from Pulicat Lake. ${ }^{10-15}$ The disparity in heavy metal concentrations attributed to the metabolic rate, exposure movement, metal movement, bioavailability and chelator species present in the Pulicat Lake sediment and water. ${ }^{19,20}$ Furthermore, environmental factors such as $\mathrm{pH}$, temperature, salinity, organic carbon, organic matter and ecosystem nutrients influence metal bioaccumulation and bioavailability. ${ }^{21}$

\section{CONCLUSION}

The present study provides evidence on the assembling of $\mathrm{Pb}, \mathrm{Fe}, \mathrm{Zn}, \mathrm{Cd}, \mathrm{Cr}$ and $\mathrm{Cu}$ from fish species $(P$. Furcatus and A. strigosus) in Pulicat lake. Though the concentrations of heavy metals in an eatable portion of fishes remained below the threshold limit recommended by Food and Agriculture Organization of the United Nations (1983), this study report and the earlier study clearly indicate the biomagnification of $\mathrm{Pb}, \mathrm{Fe}$ and other metals in the aquatic biota of Lake Pulicat.

\section{REFERENCES}

1. W.J. Langston, 1990, Toxic Effects of Metals and the Incidence of Metal Pollution in Marine Ecosystems, Furness, R.W.,Rainbow, P.S., Editors, Heavy Metals in the Marine Environment, Boca Raton: CRC Press, pp. 101-122

2. B.J. Alloway, D.C.Ayres, 1993, Chemical Principles of Environmental Pollution, London: Chapman \& Hall.

3. C.Bolognesi, E. Landini, P. Roggieri, R. Fabbri, A. Viarengo, Environmental and Molecular Mutagenesis, 33(4), 287(1999), $\quad$ DOI:10.1002/(SICI)1098-2280(1999)33:4<287::AIDEM5 $>3.0 . \mathrm{CO} ; 2-\mathrm{G}$

4. Lyla PS, Khan SA, The Indian Journal of Geo-Marine Sciences, 40117 (2011).

5. Boran, M. and Altinok, I, Turkish Journal of Fisheries and Aquatic Sciences, 10(4), 565(2010), DOI: $10.4194 /$ trjfas. 2010.0418

6. J. Fergusson, 1990, The heavy element: Chemistry, Environmental Impact and Health Effects, Pergamon Press, Oxford 614s, pp 211-212

7. M.A. Gregory, D.J. Marshall, R.C. George, A. Anandraj, T.P. McClurg, Marine Pollution Bulletin, 45(1-12) 114 (2002), DOI:10.1016/S0025-326X(01)00325-3

8. Bat, L., Gökkurt, O., Sezgin, M., Üstün, F. and Sahin, F,The Open Marine Biology Journal,3, 112 (2009), DOI: $10.2174 / 18744508009030100112$

9. F. Karayakar, O. Bavbek, B. Cicik, Journal of Aquaculture Engineering and Fisheries Research. 3(3), 141(2017), DOI: 10.3153/JAEFR 17017

10. BPD Batvari, S. Sivakumar, K. Shanthi, K.J. Lee, T.O. Byung, R.R Krishnamurthy, S KamalaKannan,Toxicology and Industrial Health, 6,1(2013), DOI: 10.1177/0748233713475500

11. BPD. Batvari, S. Kamala-Kannan, K. Shanthi, R. Krishnamoorthy, K.J. Lee and M. Jayaprakash. Environmental Monitoringand Assessment 145, 167(2008), DOI:10.1007/s10661-007-0026-3

12. BPD Batvari, S. Kamalakannan, R. R. Krishnamurthy, Journal of Chemical and Pharmaceutical Research, 7(3), 951(2015).

13. S. Kamala-Kannan, R. Krishnamoorthy,Science of the Total Environment, 367, 341(2006), DOI: 10.1016/j.scitotenv.2005.12.003.

14. S. Kamala-Kannan, BPD Batvari, Lee K.J, Kannan N, R. Krishnamoorthy, K. Shanthi, Chemosphere 71, 1233(2008), DOI:10.1016/j.chemosphere.2007.12.004.

15. S. L. Priya, B. Senthilkumar, G. Hariharan, A. P. Selvam, R. Purvaja, R. Ramesh, Toxicology and Industrial Health, 27, 117(2011), DOI: 10.1177/0748233710381892. 
RASĀYAN J. Chem.

Vol. 13 | No. 1 |195 - 201| January - March | 2020

16. S. Padma, P. Periakali, Environmental Geochemistry, 1, 55(1998).

17. P. Periakali, S. Padma, Journal of the Indian Association of Sedimentologists, 17, 239(1998).

18. B. P. Dass Batvari and V.E. N. Mariappan, Rasayan journal of Chemistry, 9(3), 424 (2016).

19. M. E. Ariza, G. N. Bijur and M.V Williams,1999, Environmental Metal Pollutants, Reactive Oxygen Intermediaries and Genotoxicity, Boston, MA: Kluwer Academic Publishers.

20. B. O. Offem, E. O. Ayotunde, Water Air and Soil Pollution, 192, 39(2008), DOI: 10.1007/s11270008-9632-0

21. Food and Agriculture Organization of the United Nations, Compilation of Legal Limits for Hazardous Substances in Fish and Fishery Products, FAO Fish Circular, 464, 5, (1983).

[RJC-5474/2019] 